Historic, Archive Document

Do not assume content reflects current scientific knowledge, policies, or practices. 



\section{Things of Beauty}

Things That Thrive

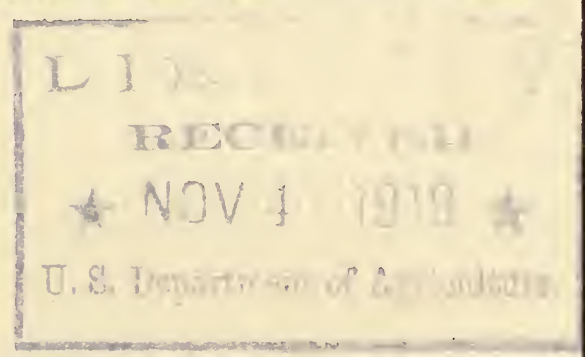

Beauty is akin to virtue.

Seek and cherish it and life will grow richer and happier.

Morningside Nursery FRED W. CARD Sylvania, Pennsylvania 
THE ZIEGLER PRINTING CO., INC.

115-117-119 E. NORTH ST.

BUTLER, PA.

(10ivificis 


\section{PEONIES}

\section{THE QUEEN OF THE LAWN}

Of all the "things that thrive," peonies are among the most easily grown, hardy, beautiful and fragrant. They thrive in any good soil, in open sun, or partial shade if not injured by tree roots. They are beautiful as single plants, in beds, borders or groups, and

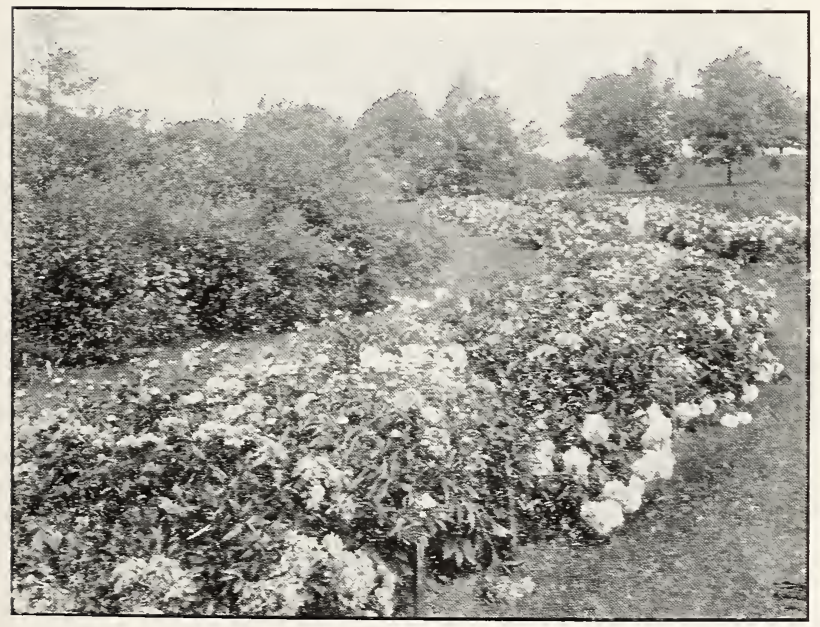

Peonies in border planting

unexcelled for interior decorations. They may be planted from August till November or in early spring, but september is best. They delight in a moist, fertile soil but object to manure near the roots. Plant so that the crowns are 2 to 3 inches below the surface. Do not expect perfect nor typical blooms the first year. 
The best six low-priced varieties, three early and three late-white, pink and redthat I have been able to find.

Festiva maxima. Most popular white peony grown; strong, vigorous grower, profuse bloomer. Large, pure white, tipped with crimson at center. Early, delightfully fragrant. 50c.

Edulis superba. A splendid early pink; freeblooming, fragrant and dependable. 25c. Louis Van Houtte. Very free-blooming, bright crimson, early; showy yellow stamens. Leaves color beautifully in autumn. 25c.

Duke of Wellington. A fine late-blooming, prolific white to follow Festiva maxima. Large, delicate creamy white, fading to pure white. Fragrant. 50c.

Humei. Extra fine, large, cinnamon-scented late pink, though not a heavy bloomer. 25c. Marechal Vaillant (Grandiflora rubra). very large, globular, compact, showy red or dark mauve pink bloom, borne on a tall heavy stem. Very late. 25c.

\section{OTHER VARIETIES}

Asa Gray. Very distinct. Bloom large, delicate, pale lilac, petals flecked with pink dots. Fragrant. $\$ 1.00$.

Baroness Schroeder. One of the finest white peonies grown. Large, globular, opening a delicate flesh white, fading to purest white. Tall, strong, fragrant, free-blooming and a good keeper. $\$ 2.50$.

Couronne d'Or (Crown of Gold). One of the best white varieties; vigorous, free-blooming, resembling Festiva maxima, but blooming late. $60 \mathrm{c}$.

Felix Crousse. Distinct in color, brilliant, cherry-red. Strong, vigorous, free-bloomer. Flowers large, full, double. 75c.

Golden Harvest. Very free-blooming, fragrant, dwarf variety of loose bomb type. Guard petals pale rose, center cream and gold, pink petals intermingled. Splendid sort. $50 \mathrm{c}$. 
La Sublime. Dark, deep red, buds almost black. Reliable, free-blooming, medium early. 50c.

La Tulipe. Attractive in bud; green and red interlaced. Flower soft blush mixed with carmine, fading to white. Fragrant and beautiful. $75 \mathrm{c}$.

Madam Ducel. Very large, globular, bombshaped, rose-pink flowers with silvery reflex. Fragrant. Strong, free bloomer, excellent. $75 \mathrm{c}$.

Marie Jacquin (Water-Lily, Bridesmaid). Distinct and beautiful, semi-double, large. Rose-white petals large, incurved, center open with rellow stamens. Resembles a water-lily. $75 \mathrm{c}$.

Old-fashioned Red ( $P$. officinalis rubra). Bright red, first to bloom. 25c.

Philomene. Distinct and novel, a strong upright grower and free bloomer. Fragrant, with bright rose guard petals, amber-yellow center and crimson tipped rose crown. $50 \mathrm{c}$.

Queen Victoria. A fine medium-early, fleshwhite variety with opening buds as delicate and fragrant as roses. Very reliable. $25 c$.

Rubra superba. A very late, crimson flower. Large, compact, excellent. 50c.

Victoria tricolor. Beautiful and effective. A single row of pink outer petals, with a central crown of creamy white. A strong grower. 25c.

\section{IRIS}

\section{THE ORCHID OF THE GARDEN}

Among the most dainty and delicate of all out-door plants. Named for the Goddess of the Rainbow, their ethereal colors and fairy-like blooms seem to have been born of the sunset skies, the rainbow hues and the tints of the morning. Most varieties are extremely hardy. Plant in August or Sep- 
tember or in early spring, about two inches below the surface, in a dry and sunny location. They will not thrive in wet soil. The great Decoration Day flower for northern latitudes.

Aurea. Fine, clear, bright yellow throughout but deeper in the throat. Flowers large and perfect. A free bloomer. 25c.

Darius. Standards rich canary yellow. Falls light violet, edged with straw-color. Rich orange beard. Distinct and beautiful. 15c.

Elegans. Standards white, tinted with lavender. Falls violet or purple-veined. Both slightly mottled with chocolate brown at base. Bright and showy. 25c.

European Yellow. A vigorous grower with deep golden yellow flowers partially hidden by leaves. 10c.

Fairy. Very delicate, glistening lavenderwhite, fragrant. Flowering stems tall; a free bloomer. Similar to Florentina but later. 25c.

Florentina. Large, delicate, lavender-white with yellow stamens and veining at base of falls. Inner petals slightly darker, pale blue midrib. Very early and fragrant. 15c.

Honorabilis. (Sans Souci). Hardy and a prolific bloomer. Standards golden yellow; falls rich mahogany brown. 10c; $\$ 5.00$ per 100 .

Madam Chereau. White, frilled with a border of lilac blue. Blooms large and keep well. 10c; $\$ 5.00$ per 100.

Mrs. H. Darwin. Pure white, falls finely reticulated, violet at the base. Free flowering, late, fragrant and beautiful. 15c.

Pallida Dalmatica. Blooms large, fine and fragrant. Delicate bright lavender, mottled with chocolate brown in the center. Fine for cut-flowers. A queen among irises, tall, stately and showy. 35c.

Perfection. Handsome and imposing; standards bright blue, falls dark velvety purple, with orange beard. $50 \mathrm{c}$.

Purple Queen. Tall, robust, bearing large showy, velvet purple flowers; early. 10c; $\$ 5.00$ per 100 . 
Queen of May. Delicate rose-lilac, approaching pink. Early and beautiful. 10c.

Orientalis. (Siberian Blue). Flowers brilliant blue, buds crimson when opening. Foliage narrow, stems tall, free-flowering and excellent for cutting. Hardy and vigorous. 15c.

Snow Queen. A fine Siberian variety with large pure ivory white flowers, yellow at the center. 25c.

Violacea grandiflora. Blooms light blue and violet blue with very delicate tints. Late and fragrant. Plant strong and vigorous. 20 c.

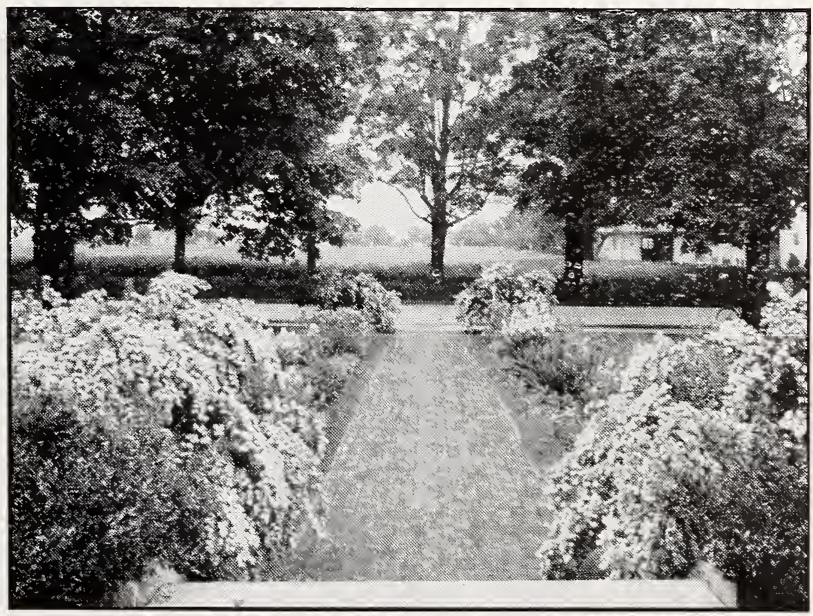

A walk bordered with Spiræa Van Houttii and iris

\section{JAPANESE IRIS}

The Japanese varieties carry the procession of iris bloom into mid-summer. The plants are tall, the blooms large and very showy. A rich, moist, well-tilled soil is best, but water must not stand over the plants in winter.

Sano-Watashi. Fine, large pure white with yellow central lines. Fine for funeral pieces. Harmonizes well with Lilium candidum. 25c.

Seedlings. Purple or white. 20c. 


\section{PHLOX}

The hardy phlox is the indispensable plant for the hot summer days of July and August when other flowers are scarce. Their bold, striking effects, coupled with their hardiness and reliability, make them general favorites. Plant either in fall or spring, in borders, beds or masses, in sunshine or partial shade. A rich, moist soil, well tilled, is the ideal. The blooming season may be retarded by pinching out the tops before the buds form, causing them to branch. Price 15c each, 2 for 25c, except as noted.

Eiffel Tower. Beautiful shell-pink. Very popular. 20c.

F. G. von Lassburg. Very large, pure porcelain-white. Fine for cutting.

Miss Lingard. An early-flowering white variety with faint lilac eye. Very freeblooming and popular; fine for massing.

Pantheon. Large, cerise-salmon with white center.

Richard Wallace. Tall, large head, pure white with maroon center.

R. P. Struthers. Bright rosy red with crimson eye.

\section{OTHER PERENNIALS}

Bleeding Heart. The fine old garden favorite. $15 c$.

Columbine. A dainty plant with light, graceful foliage and attractive bloom. Thrives in partial shade. 10c.

Native Red. (Aquilegia Canadensis) The bright red-flowered sort of eastern woodlands and mountains.

Garden Hybrids. Various kinds and colors.

Garden Pink. (Dianthus plumarius). The sweet-scented garden or grass pink. 15c. 


\section{GLADIOLUS}

\section{THE QUEEN OF THE GARDEN}

The dependable garden bulb. The beauty of an orchid with the care of a potato. Free from enemies and diseases. Fine in field or vase.

Morningside Mixture. Fine colors. 25c per $10 ; \$ 2.00$ per 100 .

Selected Pink. Large-flowered, clear pink. $5 \mathrm{c}$ each.

Selected Deep Red. Very dark, deep red.

$5 \mathrm{c}$ each.

\section{CLIMBING VINES}

Many unattractive surroundings may be transformed into objects of beauty with little cost by the judicious use of climbing vines. They should be more widely used. Price 25c each except where noted.

Clematis paniculata. One of the finest porch vines grown. A good grower, blooming abundantly in September. Flowers pure white and very fragrant.

Boston Ivy. (Ampelopsis tricuspidata). The most popular vine for covering walls of brick or stone. Clings closely, making a close thatch of bright, glossy green leaves with beautiful autumn tints. Commonly known as Ampelopsis Veitchii.

Englemann's Ivy (A. Englemanni). Similar to the Virginia Creeper, but superior. A strong grower, clinging to wood or stone. Efficient for covering dry banks, as well as trellises, dead trees, buildings, walls, etc.

Bittersweet (Celastrus scandens). An attractive native plant with glossy, lightgreen leaves and yellow flowers in June, followed by bright orange fruits retained all winter. These make attractive winter house decorations. 
Honeysuckle, Japan (Lonicera Halleana). A rapid-growing vine with handsome, lightgreen foliage. Partially evergreen. Flowers white, fragrant. A continuous bloomer. Trumpet-Vine (Tecoma radicans). A popular vine for covering old stumps or rockwork. It will cling to brick or stone. Hardy and vigorous, bearing large darkred trumpet-shaped flowers in August.

Wistaria sinensis. A popular, rapid-growing climber, bearing long, pendulous clusters of flowers in May and June. Purple or white. $35 \mathrm{c}$.

\section{ROSES}

To select a few of the best roses from the great number offered by the large rosegrowers is a difficult task for the ordinary purchaser. I have tried to cull from the many varieties a few of the hardiest and most dependable sorts which cover the principal range of colors and characters-"things that thrive." All are strong field-grown plants, quite different from the small potgrown plants so generally sold.

\section{HARDY FIELD-GROWN ROSES}

\section{Price 35c.}

Conrad Ferdinand Meyer. A hybrid rugosa rose with fine foliage, great hardiness and vigor; very fragrant. Silvery rose flowers and long pointed buds.

Frau Karl Druschki. The ideal white rose. Pure white, perfect in form and bud; vigorous and free-flowering.

General Jacqueminot. The old-time crimson favorite; reliable everywhere.

Paul Neyron. The rose for size. Very large, deep rose color, fine form.

Prince Camille de Rohan. The very dark rose. Deep, velvety crimson-maroon, approaching black.

Ulrich Brunner. The bright cherry red rose, distinct in color; strong and hardy. 
Rosa rugosa. The hardy single Japanese rose with leathery, wrinkled foliage and large red hips. Good as an ornamental shrub or hedge plant. 25c.

\section{CLIMBING ROSES}

\section{Price $35 c$.}

Excelsa. An improvement upon the wellknown Crimson Rambler. Perfectly hardy, bearing a wealth of bright crimson, semidouble flowers.

Dorothy Perkins. Splendid foliage and very hardy. Flowers clear shell-pink, fragrant, large and very double. A grand rose.

\section{HARDY SHRUBS}

Among all the plants used in decorative planting, hardy shrubs fill the most important place. They furnish foliage, bloom and fruit of a wide variety of beauty, and when planted in masses produce strong effects more quickly than can be secured in any other way. They may serve as backgrounds for flower borders, screens for unattractive buildings or outlooks and in many other ways. They require little care when once established, giving permanent results year after year, but can be readily moved if occasion requires.

Price 25c each, except where noted. Japanese Barberry (Berberis Thunbergii). Low, compact, prickly. Leaves small; fruit bright red in early winter. Very popular for hedges or specimen plants. $25 \mathrm{c} ; \$ 10$ to $\$ 15$ per 100 , according to size. Purple Barberry. Tall, upright; leaves purple.

Button-bush. Low, very attractive plant with glossy leaves, white balls of bloom and round seed-balls.

Calycanthus. Sweet-scented shrub. Flowers dark reddish brown; fragrant. 35c.

Deutzia gracilis. Very graceful, low, com- 
pact, bearing a wealth of pure white flowers. A fine plant for foregrounds. 35c. Deutzia, Pride of Rochester. A tall-growing plant bearing large, double, white flowers, tinged with pink.

Dog-wood, red-stemmed. Especially prized for its bright red twigs in winter.

The Goumi (Elacagnus longipes). A low bushy shrub with gray branches and leaves silvery beneath. Fruit cinnabarred or orange-colored, with silvery white dots, astringent but suitable for jelly.

Honeysuckle, white (Lonicera Morrowi). A fine, spreading, bushy shrub with fragrant white flowers in spring and red berries later.

Honeysuckle, pink (L. Tartarica). A hardy, showy shrub, bearing an abundance of pink flowers and berries.

Hydrangea arborescens grandiflora. Earlyflowering. A valuable, early-blooming type, flowering from June to September.

Hydrangea paniculata grandiflora. The wellknown, popular, late-flowering sort.. Flowers borne in great panicles in August and September. A very showy plant.

Japanese Quince. Low, strong, robust plant with bright red, showy flowers in early spring. Fruit showy, good for jelly.

Lilac. Common, purple or white. Wellknown favorites.

Lilac. Persian, purple or white. Dwarf, bushy, leaves narrow, flowers fragrant. $35 c$.

Lilac. Japan Tree. Leaves dark and glossy, flowers creamy white, odorless. Very hardy. Blooms in June, a month later than others. $35 \mathrm{c}$.

Lilac, Named varieties. Furnished on request.

Mahonia. Fine, low, compact, hardy, broadleaved evergreen. Leaves dark, glossy. $35 c$.

Mock Orange, early (Philadelphus coronarius). The well-known "Syringa." Tall, upright; flowers white, very fragrant.

Mock Orange, late (P. grandiflorus). Blooms late; larger, less fragrant. 
Pearl Bush (Exochorda grandiflora). neat, compact shrub covered with beautiful buds and pure white flowers in May. $35 c$.

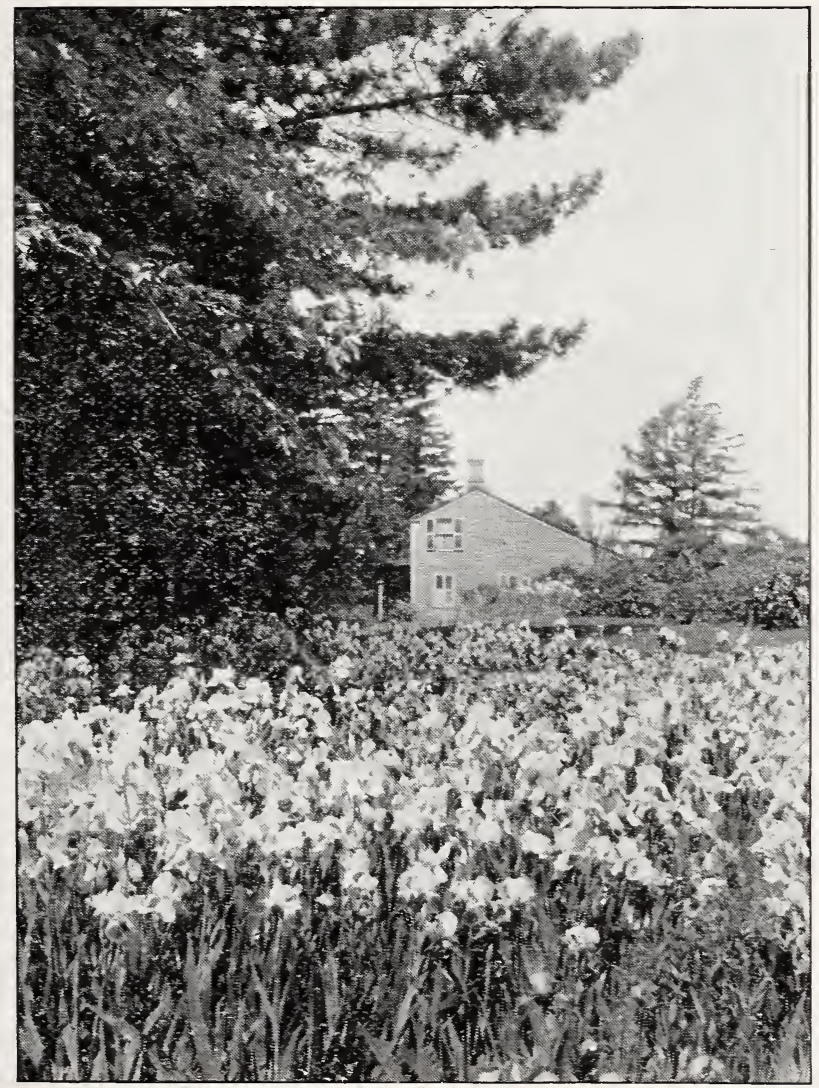

Home grounds well planted

Privet, Ibota. A Japanese species much hardier and more dependable than the California privet. $\$ 10$ to $\$ 15$ per hundred according to size.

Purple-leaved Filbert. A dense, mediumsized shrub with dark purple leaves. Hardy and beautiful for foliage effects. $50 \mathrm{c}$.

Purple Fringe or Smoke-tree (Rhus cotinus). Bears loose panicles of purplish, mist- 
like flowers, giving a smoky appearance. Foliage bright in autumn.

Rhodotypos kerrioides. Begins to bloom with the spireas and continues sparingly throughout the summer. Leaves wrinkled, attractive. Flowers white; berries black. Spiræa, Anthony Waterer (Red Flowered Spirea). Blooms all summer. Flowers red, in clusters. Plant small. Very desirable.

Spiræa prunifolia (Bridal Wreath). Branches slender and graceful, with long wands of white bloom.

Spiræa sorbifolia. Ash-leaved spirea. Ornamental and popular. Leaves resemble those of Mountain Ash. White flowers in handsome spikes in July.

Spiræa Van Houttii. The best-known and one of the most reliable spireas. One mass of white when in bloom.

snowball. The well-known garden favorite, with balls of snowy bloom.

Snowball, Japan. Leaves large, dark and handsome. Flowers fine and showy. Plant in spring. 35c.

Stephanandra. A graceful shrub with very attractive hawthorn-like foliage tinged with red in spring.

Tree Cranberry (Viburnum opulus). The fruiting form of the snowball. Bears bright red berries carried well into the winter.

Tamarisk, Russian. A graceful, airy shrub with feathery grayish-green foliage and delicate pink flowers. A very attractive plant.

Weigelas. Splendid, hardy, dependable flowering shrubs, blooming abundantly and lasting a long time.

W. candida. Flowers pure white.

Eva Rathke. Deep scarlet or crimson.

W. rosa. Pink or rose colored. 


\section{ASK FOR WHAT YOU WANT}

My aim in choosing what to grow and to offer has been to select things that are both distinct and dependable, that are really worth growing-."things that thrive." I believe the list may save you time in selecting and disappointment in growing, but if you want other varieties or other lines of nursery stock which we do not grow, we shall be glad to quote you prices or add them to your order if given time. We can generally save you money by doing so.

\section{LARGE ORDERS}

For prices by the dozen or hundred, make the following deductions from the price of single plants:

5 or more plants of the same kind and va. riety, 20 per cent discount.

50 or more plants of the same kind and variety, 25 per cent discount.

\section{PLANTS BY MAIL}

We will prepay postage on peonies, iris and other perennials and climbers, within the first, second and third zones, when ordered at the single rates, but must choose lighter plants of most kinds. Postage on gladolius bulbs, $10 \mathrm{c}$ per ten. We can also usually furnish small plants of roses and shrubs at the single rates prepaid, but advise express shipments.

Make of your home a picture, painted upon a canvas of lawn, in colors of living green, studded with stars of bloom 
